\title{
Nutrition Education of Booklet Media on Knowledge and Nutritional Intake of Obese Adolescents in Palembang \\ $1^{\text {st }}$ Mardiana Nutrition Department \\ Polteknik Kesehatan Kemenkes Palembang Palembang, Indonesia \\ Email: mardianaagus42@yahoo.com

\author{
$2^{\text {nd }}$ Yulianto \\ Nutrition Department \\ Polteknik Kesehatan Kemenkes Palembang \\ Palembang, Indonesia \\ Email: youllee64@yahoo.co.id
}

Corresponding author: youllee64@yahoo.co.id

Abstract - One of the nutritional problems that occur in adolescents is overweight (obesity) caused by high food intake but not balanced by adequate physical activity and high-calorie diets but contain little fiber. The 2013 Basic Health Research Data shows that the prevalence of obesity among adolescents aged 16-18 years is $1.6 \%$ while the prevalence of obesity in South Sumatra Province is higher than the national level of $4.8 \%$. This study aims to look at the Effect of Media Booklet Nutrition Education on Knowledge and Adolescent Nutrition for Obesity in Palembang City. This type of quasi experimental research design PreTest - PostTest with control. The research sample was 70 obese adolescents in SMA and SMK Methodist 2 in Palembang. The treatment group got the intervention in the form of lectures and booklets 4 times while the comparison group was only given lectures. Data were analyzed using paired t-test and independent t-test. The results showed that the average knowledge score in obese adolescents who got lectures and booklets increased by 2.69 while the intake of energy, protein, fat, carbohydrates and weight decreased. In the comparison group the average knowledge score only increased by 1.06 while the intake of energy, protein, fat, carbohydrates, and body weight increased. Nutrition education through media booklets and lectures increases knowledge and nutrition intake in obese adolescents compared to lecture methods alone

Keywords: Media and booklet, Knowledge, nutrition, obesity.

\section{INTRODUCTION}

Obesity in adolescents is a health problem that needs special attention remembering the adverse effects of obesity on health is closely related to various serious diseases, such as high blood pressure, heart disease, diabetes mellitus, and respiratory disease. Another impact that is often overlooked is the feeling of feeling different or distinguished from the group willmake individuals with obesity vulnerable to various psychological problems. Obese adolescents who are shunned by their friends tend to experience a great sense of hopelessness and easily feel isolated or offended [1].

In Indonesia, the prevalence of obese adolescents in adolescents aged 16-18 years is $1.6 \%$, and the prevalence of obesity in South Sumatra Province is $4.8 \%$. There are 3 districts / cities with the highest obesity prevalence, namely: Prabumulih, East OKU, and Natural Fence [2]. Whereas in Palembang the Obesity prevalence was $14.1 \%$ [3].

Booklet is a media to deliver health messages in the form of books with a combination of writing and pictures so that they attract attention. The advantages of the booklet media are information that is written more fully, in more detail and clearly and is educative in nature. In addition, this booklet that is used as an educational medium can be taken home, so that it can be read over and over again and stored.

Methodist 2 Vocational High School and Methodist 2 Vocational High School are schools with an average of students coming from families with middle to upper economic level and have been known by previous studies on Palembang Methodist 2 Vocational School students out of 233 students there were $11.58 \%$ students who are obese this is what made researchers interested in conducting research on Nutrition Education through Lectures and Booklets on Obese Adolescents in Methodist 2 Vocational High School and Methodist 2 High. School Palembang. 


\section{MethodS}

This type of research is a Quasi Experiment using the design of PreTest-Post Test with Control. In this study the treatment group was given education through lectures on nutrition and health as well as a booklet on how to overcome obesity in adolescents. The treatment given was 4 times whereas in the control group only given lectures on nutrition and health.

The research is located at SMA Methodist 2 and SMK Methodist 2 Palembang, conducted in September to November 2019.

The population in this study were all obese students in SMA Methodist 2 and SMK Methodist 2 Palembang. Samples were 70 people. The sampling technique used was simple random sampling so as to get 35 people as a treatment group and 35 people as a comparison group.

Information on the characteristics of respondents consisting of age, class, gender, father's occupation, mother's occupation was obtained using a questionnaire that was filled in by the respondent himself. Whereas anthropometric data of body weight were obtained by weighing respondents using digital scales and respondent's height data obtained by measuring using microtoise. Knowledge data obtained from questionnaires filled out by direct respondents. Data on fast food consumption is obtained from the FFQ semiquantitative fast food questionnaire as a result of interviews with respondents.

All of this data is taken before the intervention and after the intervention.

Knowledge value is obtained from interviews with respondents who have filled all the questions in the questionnaire. Score is the number of correct answers per item. If it is true get a score of one, whereas if one gets a zero score After that an average calculation of all the questions is done. In adolescent fast food consumption, the data collection was carried out by interviewing respondents using a semi-FFQ questionnaire, to see how often students consumed fast food in pre and post.

Furthermore, the data were analyzed univariately, to see the frequency distribution and percentage of each variablethen continued with bivariate analysis, using the Paired $t$ testto process pre and post intervention data and independent samplesttesttotreatpreandpostbetweentreatmentgroups and control.

\section{RESUlT}

Characteristics of respondents are presented in table 1

Table 1. Distribution of Characteristicsof Respondents

\begin{tabular}{|c|c|c|}
\hline \multirow[t]{2}{*}{ Characteristics } & \multicolumn{2}{|c|}{ amount } \\
\hline & $\mathrm{n}$ & $\%$ \\
\hline \multicolumn{3}{|l|}{ Age(Years) } \\
\hline 16 years & 37 & 52.86 \\
\hline 17 years & 27 & 38.57 \\
\hline 18 years & 6 & 8.57 \\
\hline Total & 70 & 100.0 \\
\hline \multicolumn{3}{|l|}{ Gender } \\
\hline Male & 40 & 57.1 \\
\hline Female & 30 & 42.9 \\
\hline Total & 70 & 100.0 \\
\hline \multicolumn{3}{|l|}{ Father'sEducation } \\
\hline Not completed in & 2 & 2.9 \\
\hline \multicolumn{3}{|l|}{ primary school } \\
\hline Elementary School & 11 & 15.7 \\
\hline Junior High School & 10 & 14.3 \\
\hline Senior High Shcool & 41 & 58.6 \\
\hline College & 6 & 8.5 \\
\hline Total & 70 & 100.0 \\
\hline \multicolumn{3}{|l|}{ Mother'sEducation } \\
\hline $\begin{array}{l}\text { Not completed in } \\
\text { primaryschool }\end{array}$ & 2 & 2.9 \\
\hline Elementary School & 10 & 14.3 \\
\hline Junior High School & 14 & 20.0 \\
\hline Senior High School & 38 & 54.3 \\
\hline College & 6 & 8.5 \\
\hline Total & 70 & 100.0 \\
\hline \multicolumn{3}{|l|}{ Father'soccupation } \\
\hline Private & 17 & 24.3 \\
\hline Entrepreneur & 52 & 74.3 \\
\hline Civil servants & 1 & 1.4 \\
\hline Total & 70 & 100.0 \\
\hline \multicolumn{3}{|l|}{ Mother'soccupation } \\
\hline Private & 3 & 4.3 \\
\hline Entrepreneur & 16 & 22.8 \\
\hline Civil servants & 2 & 2.9 \\
\hline Housewife & 49 & 70.0 \\
\hline Total & 70 & 100.0 \\
\hline
\end{tabular}

Most of the respondents aged 16 years were 52.86, male sex as much as $57.1 \%$. The education of high school fathers was $58.6 \%$ and the education of high school mothers was $54.3 \%$. The occupation of fathers self-employed was $74.3 \%$. Whereas the majority of respondents were housewives, $70.0 \%$ ) 
The Average Knowledge of Nutrient Intake and Weight Before and After the Intervention can be seen in table 2

Table 2. Knowledge of Nutrient Intake and Weight Before and After the Intervention

\begin{tabular}{|c|c|c|c|c|c|c|c|c|}
\hline \multirow{2}{*}{$\begin{array}{l}\text { Variab } \\
\text { e }\end{array}$} & & \multirow{2}{*}{$\mathbf{n}$} & \multicolumn{4}{|c|}{ Treatment } & \multicolumn{2}{|c|}{$\begin{array}{c}\text { Compari } \\
\text { son }\end{array}$} \\
\hline & & & $\begin{array}{l}\text { Mi } \\
\text { n }\end{array}$ & $\begin{array}{l}\text { Ma } \\
\text { ks }\end{array}$ & $\begin{array}{l}\text { Mean } \\
\pm \text { SD }\end{array}$ & Min & $\begin{array}{l}\text { Mak } \\
\text { s }\end{array}$ & $\begin{array}{l}\text { Mean } \\
\pm \text { SD }\end{array}$ \\
\hline Knowle & Pre & 35 & 5 & 13 & $\begin{array}{l}10.34 \pm \\
2.19 \\
\end{array}$ & 2 & 13 & $\begin{array}{l}10.28 \pm \\
2.14 \\
\end{array}$ \\
\hline dge & Pos & 35 & 9 & 15 & $\begin{array}{l}13.03 \pm \\
1.50\end{array}$ & 7 & 14 & $\begin{array}{l}11.34 \pm \\
1.43\end{array}$ \\
\hline P value & & 35 & 0.000 & & & 0,010 & & \\
\hline $\begin{array}{l}\text { Energy } \\
\text { intake }\end{array}$ & Pre & 35 & $\begin{array}{l}23 \\
98 . \\
76 \\
\end{array}$ & $\begin{array}{l}286 \\
8.7 \\
5 \\
\end{array}$ & $\begin{array}{l}2624.4 \\
8 \pm 131 \\
67 \\
\end{array}$ & $\begin{array}{l}2387 \\
.09\end{array}$ & $\begin{array}{l}2893 \\
.67\end{array}$ & $\begin{array}{l}2594.7 \\
5 \pm 116 . \\
63\end{array}$ \\
\hline (Kkal) & Pos & 35 & $\begin{array}{l}23 \\
00 . \\
42\end{array}$ & $\begin{array}{l}279 \\
0.2 \\
1\end{array}$ & $\begin{array}{l}2549.6 \\
5 \pm 109 \text {. } \\
98\end{array}$ & $\begin{array}{l}2410 \\
.32\end{array}$ & $\begin{array}{l}2862 \\
.34\end{array}$ & $\begin{array}{l}2630.3 \\
4 \pm 121 \\
14\end{array}$ \\
\hline P value & & 35 & 0.000 & & & 0.047 & & \\
\hline Protein & Pre & 35 & $\begin{array}{l}55 . \\
98 \\
\end{array}$ & $\begin{array}{l}75 . \\
57\end{array}$ & $\begin{array}{l}63.42 \pm \\
4.98 \\
\end{array}$ & $\begin{array}{l}54.7 \\
6 \\
\end{array}$ & $\begin{array}{l}72.6 \\
0 \\
\end{array}$ & $\begin{array}{l}64.21 \pm \\
5.55 \\
\end{array}$ \\
\hline $\begin{array}{l}\text { intake } \\
(\mathrm{g})\end{array}$ & Pos & 35 & $\begin{array}{l}52 . \\
89\end{array}$ & $\begin{array}{l}71 . \\
23\end{array}$ & $\begin{array}{l}62.63 \pm \\
4.95\end{array}$ & $\begin{array}{l}57.4 \\
8\end{array}$ & $\begin{array}{l}74.6 \\
7\end{array}$ & $\begin{array}{l}65.28 \pm \\
6.18\end{array}$ \\
\hline Pvalue & & 35 & 0.165 & & & 0.455 & & \\
\hline $\begin{array}{l}\text { Fat } \\
\text { intake }\end{array}$ & Pre & 35 & $\begin{array}{l}86 . \\
00\end{array}$ & $\begin{array}{l}107 \\
.39\end{array}$ & $\begin{array}{l}97.90 \pm \\
6.09\end{array}$ & $\begin{array}{l}86.5 \\
0 \\
\end{array}$ & $\begin{array}{l}105 . \\
18\end{array}$ & $\begin{array}{l}96.42 \pm \\
5.23\end{array}$ \\
\hline (g) & $\begin{array}{l}\text { Pos } \\
t\end{array}$ & 35 & $\begin{array}{l}59 . \\
23\end{array}$ & $\begin{array}{l}104 \\
.13\end{array}$ & $\begin{array}{l}92.11 \pm \\
10.07\end{array}$ & $\begin{array}{l}105 . \\
59\end{array}$ & $\begin{array}{l}110 . \\
27\end{array}$ & $\begin{array}{l}97.31 \pm \\
12.00\end{array}$ \\
\hline $\begin{array}{l}P \\
\text { value }\end{array}$ & & 35 & 0.052 & & & 0.334 & & \\
\hline & & 35 & 34 & 389 & 368.51 & 327. & 398. & 361.50 \\
\hline $\begin{array}{l}\text { Carbo } \\
\mathrm{h}\end{array}$ & Pre & & 5.3 & .76 & \pm 13.53 & 78 & 09 & \pm 16.16 \\
\hline ydrate & & & 4 & & & & & \\
\hline $\begin{array}{l}\text { intake } \\
\text { (g) }\end{array}$ & Pos $t$ & 35 & $\begin{array}{l}33 \\
6.73\end{array}$ & $\begin{array}{l}389 \\
.70\end{array}$ & $\begin{array}{l}363.14 \\
\pm 14.02\end{array}$ & $\begin{array}{l}321 . \\
35\end{array}$ & $\begin{array}{l}399 . \\
95\end{array}$ & $\begin{array}{l}374.42 \\
\pm 18.17\end{array}$ \\
\hline $\begin{array}{l}\mathrm{P} \\
\text { value }\end{array}$ & & 35 & 0.000 & & & 0.000 & & \\
\hline & Pre & 35 & 65. & 105 & $78.12 \pm$ & 65.2 & 123. & $83.66 \pm$ \\
\hline $\begin{array}{l}\text { Weig } \\
\text { ht }\end{array}$ & & & 80 & .70 & 10.15 & 0 & 00 & 13.34 \\
\hline$(\mathrm{Kg})$ & Pos & 35 & 64. & 104 & $77.10 \pm$ & 65.2 & 122. & $84.22 \pm$ \\
\hline & $\mathrm{t}$ & & 00 & .20 & 10.19 & 0 & 00 & 14.94 \\
\hline $\begin{array}{l}\mathrm{P} \\
\text { value }\end{array}$ & & 35 & 0.000 & & & 0.000 & & \\
\hline
\end{tabular}

The average knowledge of treatment and comparison has increased. But the treatment knowledge increased by 2.69 and the comparison increased by 1.06 . In the treatment of decreased energy in take ie $74.83 \mathrm{kcal}$, protein decreased by0.79 g. Fat decreased $5.79 \mathrm{~g}$, carbohydrate decreased $5.37 \mathrm{~g}$ and body weight decreased $1.02 \mathrm{~kg}$. Whereas in comparison energy intake increased by $35.49 \mathrm{kcal}$, protein increased by $1.07 \mathrm{~g}$, fat increased by $1.33 \mathrm{~g}$, carbohydrate increasedby $12.92 \mathrm{~g}$ and body weight increased by $0.56 \mathrm{~kg}$.

Differences in mean knowledge, energy intake, carbohydrates, and body weight before and after education in the treatment and comparison groups ( $\mathrm{p}$ $<0.05)$. Whereas the variable protein and fat intake $p$ value $>0.05$ which means that there is no difference in the mean before and after education in the treatment and comparison groups.

Table 3. Differences in mean knowledge, nutrient intake and body weight before and after lecture intervention and booklet distribution between treatment and comparisongroups

\begin{tabular}{|c|c|c|c|c|}
\hline & Treatment & Comparison & Error & \\
\hline $\begin{array}{l}\text { Variabl } \\
\text { e }\end{array}$ & $\begin{array}{l}\text { Difference } \pm \\
\text { SD }\end{array}$ & Difference \pm SD & ard & $\begin{array}{l}P \\
\text { value }\end{array}$ \\
\hline Knowledge & $1.34 \pm 0.92$ & $0.52 \pm 1.15$ & 0.31 & 0.001 \\
\hline $\begin{array}{l}\text { Energy } \\
\text { Intake } \\
\text { (Kcal) }\end{array}$ & $46.45 \pm 32.00$ & $55.19 \pm 46.76$ & $\begin{array}{c}14.7 \\
6\end{array}$ & 0.014 \\
\hline $\begin{array}{l}\text { Protein } \\
\text { Intake } \\
\text { (g) }\end{array}$ & $0.64 \pm 1.54$ & $1.78 \pm 3.18$ & 0.55 & 0.062 \\
\hline $\begin{array}{l}\text { Fat Intake } \\
(\mathrm{g})\end{array}$ & $95.00 \pm 6.69$ & $95.58 \pm 7.74$ & 1.67 & 0.740 \\
\hline $\begin{array}{l}\text { Carbohy } \\
\text { drate } \\
\text { Intake } \\
\text { (g) }\end{array}$ & $3.26 \pm 2.44$ & $1.12 \pm 8.96$ & 1.04 & 0.016 \\
\hline $\begin{array}{l}\text { Weight } \\
(\mathrm{Kg})\end{array}$ & $0.57 \pm 0.31$ & $0.83 \pm 1.38$ & 0.14 & 0.021 \\
\hline
\end{tabular}

Information: independent t-test

Table 3. shows differences in knowledge, energy intake, carbohydrate intake and body weight between the treatment group and the comparison group ( $p$ $<0.05)$. Whereas in the protein and fat intake variables there were no mean differences between treatment and comparison groups $(\mathrm{p}>0.05)$.

\section{DISCUSSION}

The last level of education both the father and mother respondents were mostly high school. Higher parental 
education increases opportunities for getting more decent work so that the income earned is also higher which will have an impact on determining needs, access to information, and access to health that is more fulfilled. This is in line with research by [4]. Stating that parental past education will affect family in come.

The majority of respondent's father worked as an entrepreneur while half the respondent's mother did not work. Parents' work is related to family income, the higher the family's income, the ability to meet nutritional needs will also be better, besides that health access tends to be easier to obtain. The income level will also affect lifestyle which will have an impact on nutritional status.

The univariate analysis showed an increase in knowledge in the treatment group and the comparison group. However, in the treatment group the increase in knowledge was more than the comparison group, namely the ratio of 2.69 while in the comparison group of 1.06. This research was conducted lectures on adolescents 4 times for the comparison group while in the treatment group was given lectures 4 times and the Knowledge booklet was the result of human sensing, or the result of knowing someone about an object through their senses (eyes, nose, ears, etc.). The increase in knowledge scores occurs because of the information provided through nutrition education, a change from initially not knowing to knowing. This is also in line with the opinion of the theory which states that knowledge is what has been known and able to be remembered by someone after he experienced, witnessed and understood or obtained from birth until he became an adult both obtained through formal and non-formaleducation.

The average energy intake in the intervention group experienced a loss late while apada comparison group experienced an increase. Energy is needed for the continuity of processes in the body such as the process of circulation and circulation of blood, heart rate, breathing, digestion, other physiological processes to move or do physical work. Energy in the body can arise due to the burning of carbohydrates, proteins and fats, so in order for sufficient energy needs to be enough food intake by consuming adequate and balanced food [5].

This study shows that protein intake in the treatment group decreased while in the comparison group it increased. Protein requirements are the consumption needed to prevent loss of body protein and allow the production of protein needed during growth, pregnancy or breastfeeding. Excessive protein also does not benefit the body. Foods that are high in protein are usually high in fat too, so they cause obesity[6].
Fat is a substance that looks like wax and does not dissolve in water. Fat contained in food substances generally consists of acombination of three groups of fatty acids and glycerol and is known as triglycerides [7]. The human body has unlimited ability to store fat. In this study $\mathrm{k}$ el Ompok treatment decreased fat intake while on treatment increased.

The results of previous studies showed that the treatment group experienced a decrease while the comparison group experienced an increase. Carbohydrate requirements are $55-77 \%$ of the total energy consumption mainly from complex carbohydrates and $10 \%$ from simple sugars. In this study the weight of the treatment decreased from 78.12 $\mathrm{kg}$ to $77,10 \mathrm{~kg}$ while the mean in the comparison group experienced an increase in body weight. that is, from $83.66 \mathrm{~kg}$ to $84.22 \mathrm{~kg}$., adolescent girls will gain weight as much as $8.3 \mathrm{~kg}$ per year during the peak weight gain that occurs around the age of 12.5 years. At puberty weight gain in adolescent girls is an average of $17.5 \mathrm{~kg} /$ year. Whereas adolescent boys experience an average weight gain of $9 \mathrm{~kg} /$ year [8].

The mean knowledge of the treatment group was 2.69 higher than the average knowledge in the comparison group that was1.06. In the comparison group only verbal information was given for \pm 30 minutes given 4 times face to face. Whereas the treatment group received lectures and booklets.

The results showed that of the 15 questions given there were still many respondents who did not know about the causes of obesity, how many targets per month were recommended for weight loss, obesity categories (BMI / U) and nutrients contained in vegetables and fruits as well as balanced nutrition menu.

Changes and increase in the value of knowledge may be due to the role of the media in the process of nutrition education, among others, teaching attracts more attention of students so that it can foster student motivation, education is more directed along with appropriate material delivery methods so that the process of nutrition education runs well and the sample is easy to understand the contents of the material submitted [9].

This is in line with research conducted by [7]. where the average increase in nutritional knowledge in the lecture group from the previous was $72.99 \%$ to $78.88 \%$, while in the booklet group the average knowledge before education was $73.96 \%$ to $78.89 \%$. which shows that booklets are influential in increasing adolescent knowledge. The process of nutrition education is inseparable from the influence of the use of teaching aids or media that can support the ongoing educational activities. Media functions to facilitate 
someone in understanding information that is considered complicated. This is in accordance with the purpose of providing nutrition education which is to produce increased knowledge that will influence[7].It is not only the media that plays a role but also the method of its delivery. The lecture method in this case stimulates thesense of hearing. The more senses involved, the more effective the process of delivering information [10].

Most of the teenagers in this study prefer to consume fast food or fast food, this is due to various reasons such as it tastes better, is practical, easy to obtain because the location of the school located in the middle of the city makes respondents prefer to consume fast food food.

Based on the results of the data on the FFQ questionnaire form, high-calorie snacks that are often consumed are fried chicken, meatballs and pizza. A similar study was revealed by [11]. the results of the study showed that obese adolescents had a higher average energy intake of $3627.8 \mathrm{kcal}$ compared to non-obese adolescents of $3368.5 \mathrm{kcal}$.

Based on the results of the data on the questionnaire form FFQ, it is found that the intake of protein which is often consumed is meat, eggs, sausages andnuggets.

The results of this study are consistent with the results of the study by [6] there is no relationship between protein intake and obesity, that by consuming a lot of protein can reduce excess fat in the stomach area[8].

Based on the results of the data on the FFQ questionnaire form, the intake of fat that is often consumed is fried food, fast food such as fried food and fried chicken.

The results of this study are in line with the results of the study by [12]. whostated the results of the analysis of the relationship test showed that there was no relationship between fat intake and obesity status ( $p$ $=0.240$ ).

These results are consistent with research conducted [5]. on the effects of nutritional education on changes in energy consumption and body mass index in overweight adolescents, the results of which show visible changes that subjects learn to be selective in choosing foods that are tailored to the body's needs. .

[13] research results stated that increasing knowledge about nutrition in overweight adolescents can reduce adolescent BMI $(\mathrm{p}<0.05)$.

The process of nutrition education is inseparable from the influence of the use of teaching aids or media that can support the ongoing educational activities. Media functions to facilitate someone in understanding information that is considered complicated. This is in accordance with the purpose of providing nutrition education which is to produce increased knowledge that will influence [7].

It is not only the media that plays a role but also the method of its delivery. The lecture method in this case stimulates the sense of hearing. The more senses involved, the more effective the process of delivering information [10].

\section{CONCLUSION}

The results showed that the knowledge score in the treatment group increased by 2.69 , while the intake of energy, protein, fat, carbohydrates and weight decreased after being given education media lectures and booklets. And in the comparison group the knowledge score only increasedby1.06 while the intake of energy, protein, fat, carbohydrates, and body weight increased. Educational nutrition through media booklets and talks over increasing knowledge and nutrition ririskiky a meaningful than justlecturing.

\section{ACKNOWLEDGMENT}

Thank you to the Director of the Palembang Health Ministry of Health Polytechnic for providing financial assistance, reviewers, Ethics Commission Polytechnic Health Ministry Makassar, Principals of Palembang High School and SMK Methodist 2 and all respondents who participated in this study.

\section{REFERENCES}

[1] Kinanti I. Gambaran Citra Tubuh Pada Remaja yang Obesitas. Skripsi 2010

[2] Depkes. Laporan Nasional Riskesdas 2007. Badan Penelitian dan Pengembangan Kesehatan Departemen Kesehatan, Republik Indonesia 2008:1-384.

[3] Depkes. HasilRiskesdas 2013. Jakarta: 2013

[4] Makarimah A. Hubungan Antara Status Gizi, Persen Lemak Tubuh, Pola Konsumsi, danA ktivitas Fisik Dengan Usia Menarche Anak Sekolah Dasar. Skripsi 2017.

[5] Widhayati RE. The Effect of Nutrition Education on Energy Consumption and Body Mass Index in Overweight Adolescents. Univ Stuttgart 2009:1-134.

[6] Suryandari, B D; Widyastuti N. Hubungan Asupan Protein dengan Obesitas Pada Remaja. Journal Nutr Coll 2015;4:492-8.

[7] Nurul Riau Dwi Safitri DYF. Pengaruh Edukasi Gizi dengan Ceramahdan Booklet Terhadap Peningkatan Pengetahuan dan Sikap Gizi Remaja Overweight. Journal of Nutrition College 2016;5:374-80.https://doi.org/10.14710/jnc.v5i4.16438.

[8] Restianti N. Hubungan Citra Tubuh, Asupan Energi dan Zat Gizi Makro Serta Aktivitas Fisik dengan Status Gizi Lebih pada Siswa Smp Muhammadiyah 31 Jakarta Timur Tahun 2012. Skripsi 2012. 
[9] KhairunaHamida ,SitiZulaekah M. Penyuluhan Gizi Dengan Media Komik Untuk Meningkatkan Pengetahuan Tentang Keamanan Makanan Jajanan. Jurnal Kesehatan Masyarakat. 2012;8:67-73.

[10] Isnawati Dwi Utami. Pengembangan Media Busy Book Materi Aturan Dalai Keluarga Untuk Kelas III Sd Negeri Panggang Sedayu, Bantul. Yogyakarta: 2018.

[11] Kurdanti W, Suryani I, Syamsiatun NH, Siwi LP, Adityanti MM, Mustikaningsih D, Et Al. Faktor-faktor yang Memengaruhi Kejadian Obesitas pada Remaja. Jurnal Gizi Klinik Indonesia 2015;11:179.https://doi.org/10.22146/ijcn.22900

[12] Simbolon D, Tafrieani W, Dahrizal D. Edukasi Gizi dan Perubahan Berat Badan Remaja Overweight dan Obesitas. Jurnal Kesehatan. 2018;9:289-94. https://doi.org/10.26630/jk.v9i2.841.

[13] Nurmasyita N, Widjanarko B, Margawati A. Pengaruh Intervensi Pendidikan Gizi Terhadap Peningkatan Pengetahuan Gizi, Perubahan Asupan Zat Gizi dan Indeks Massa Tubuh Remaja Kelebihan Berat Badan. Jurnal Gizi Indonesia 2016;4:38-47. https://doi.org/10.14710/jgi.4.1.38-47. 